\title{
Integrated evaluation of the geology, aerogammaspectrometry and aeromagnetometry of the Sul-Riograndense Shield, southernmost Brazil
}

\author{
LÉO A. HARTMANN ${ }^{1}$, WILLIAM R. LOPES ${ }^{2}$ and JAIRO F. SAVIAN ${ }^{1}$ \\ ${ }^{1}$ Instituto de Geociências, Universidade Federal do Rio Grande do Sul, Avenida Bento \\ Gonçalves, 9500, Agronomia, 91501-970 Porto Alegre, RS, Brasil \\ ${ }^{2}$ Gerência de Geologia e Mineração, Serviço Geológico do Brasil (CPRM), Rua Banco da \\ Província, 105, Morro Santa Tereza, 90840-030 Porto Alegre, RS, Brasil
}

Manuscript received on September 22, 2014; accepted for publication on July 29, 2015

\begin{abstract}
An integrated evaluation of geology, aerogammaspectrometry and aeromagnetometry of the Sul-Riograndense Shield is permitted by the advanced stage of understanding of the geology and geochronology of the southern Brazilian Shield and a 2010 airborne geophysical survey. Gamma rays are registered from the rocks near the surface and thus describe the distribution of major units in the shield, such as the Pelotas batholith, the juvenile São Gabriel terrane, the granulite-amphibolite facies Taquarembó terrane and the numerous granite intrusions in the foreland. Major structures are also observed, e.g., the Dorsal de Canguçu shear. Magnetic signals register near surface crustal compositions (analytic signal) and total crust composition (total magnetic signal), so their variation as measured indicates either shallow or whole crustal structures. The Caçapava shear is outstanding on the images as is the magnetic low along the N-S central portion of the shield. These integrated observations lead to the deepening of the understanding of the largest and even detailed structures of the Sul-Riograndense Shield, some to be correlated to field geology in future studies. Most significant is the presence of different provinces and their limits depending on the method used for data acquisition - geology, aerogammaspectrometry or aeromagnetometry.
\end{abstract}

Key words: Aeromagnetometry, aerogammaspectrometry, gamma spectrometric provinces, magnetic provinces, Sul-Riograndense Shield.

\section{INTRODUCTION}

This is an integrated evaluation of the geology and aerogammaspectrometric and aeromagnetometric survey of the Brazilian Shield in the southernmost state of Rio Grande do Sul, Brazil. All three lines of interpretation are presently in an advanced stage of data acquisition, so the integration is most

Correspondence to: Léo Afraneo Hartmann

E-mail: leo.hartmann@ufrgs.br significant. The aerogammaspectrometric method reads the direct response from the surface geology, and the aeromagnetometric method provides information below the surface cover of soil and sedimentary rocks and water. We use a combination of differential reduction to pole map with the analytical signal to interpret the aeromagnetic data.

The geology of the Sul-Riograndense Shield has been studied for one hundred years, most intensely in the last three decades, both by the Geological 
Survey of Brazil (e.g., Bizzi et al. 2003) and by university researchers, resulting in overviews by Jost and Hartmann (1984), Fragoso-César et al. (1986), Fernandes et al. (1992, 1995a), Chemale et al. (1995a, b), Hartmann et al. (2000, 2007), Chemale (2000), Basei et al. (2000), Heilbron et al. (2004), Philipp and Machado (2005), Saalmann et al. (2011) and Philipp et al. (2008, 2013). Field mapping was integrated in recent years with voluminous zircon dating, mostly with the sensitive high resolution ion microprobe (SHRIMP), so this portion of the Brazilian Shield is known to contain limited exposures of Archean rocks. It is dominated by Paleoproterozoic and Neoproterozoic rocks, and Statherian (Paleoproterozoic) and Calymmian (Mesoproterozoic) units have been recently described (Camozzato et al. 2013). Detrital and inherited 1.2-1.0 Ga old zircons are common, but no outcropping source rock has been identified. The age of the Capivarita Anorthosite was established at $1573 \pm 21$ Ma by Chemale et al. (2011). Significant $\mathrm{U}-\mathrm{Pb}$ (and some Lu-Hf) isotopic detrital zircon studies (e.g., Lena et al. 2014, Lopes et al. 2014) shed additional light on the significance of the main geotectonic provinces of the shield. The varied studies by several groups of investigators led to this confusing geotectonic terminology, briefly described in Table I.

An airborne geophysical survey of the shield was undertaken in 1974 by the Geological Survey of Brazil, including gamma spectrometric and gravimetric signals (e.g., Costa 1997, Costa et al. 1995, Costa and Ramgrab 1989, Fernandes et al. 1995b, Koester et al. 1999). A recent (CPRM 2010) airborne geophysical survey by the same institution resulted in the precise distribution of the gamma spectrometric and magnetometric signals over the shield, so it is used as the main base for this first integrated evaluation with geology. The authors make use of their expertise in geology and geophysics to obtain significant results in this study of the geology and geophysics of the SulRiograndense Shield.

\section{MATERIALS AND METHODS}

The accumulated experience over several decades by the authors is presently integrated with knowledge acquired by several generations of geologists in the study of the Sul-Riograndense Shield. The compilation of reports by the Geological Survey of Brazil is presently integrated with the knowledge developed at several universities, particularly Universidade Federal do Rio Grande do Sul but also Universidade do Vale do Rio dos Sinos and Universidade de São Paulo. These studies included field mapping, aerogeophysics (1974 survey by the Geological Survey of Brazil), petrography, structural geology, rock geochemistry, chemical analyses of minerals, and particularly the $\mathrm{U}-\mathrm{Pb}$ dating of zircon, added to the $\mathrm{Sm}-\mathrm{Nd}$ isotopic determinations on rock samples. These extensive studies include the publications by Hasui et al. (1975), Sartori and Ruegg (1979), Jost and Bitencourt (1980), Hartmann and Nardi (1982), Bitencourt and Hartmann (1984), Soliani Jr (1986), Nardi and Bitencourt (1989), Machado et al. (1990), Nardi and Bonin (1991), Nardi and Frantz (1995), Hartmann (1998, 2002), Leite et al. (1998, 2000), Hartmann et al. (1999, 2001, 2003, 2004, 2008, 2011), Remus et al. (1999, 2000a, b), Bitencourt and Nardi (2000), Frantz and Botelho (2000), Lopes and Hartmann (2003), Frantz et al. (2003), Santos et al. (2003), Hartmann and Santos (2004), Silva et al. (2005), Saalmann et al. (2005a, b, c, 2006a, b), Sommer et al. (2005), Gross et al. (2006), Philipp et al. (2008) and Gregory et al. (2015).

The novel approach presently used is the availability of the airborne geophysical survey of the shield by the Geological Survey of Brazil (CPRM 2010), including aerogammaspectrometry and aeromagnetometry. Data acquisition was made by LASA PROSPECÇÕES S.A. (CPRM 2010). The flight was at an elevation of $100 \mathrm{~m}$ above the terrain, line spacing at $500 \mathrm{~m}$ and control lines 
TABLE I

Glossary of geological nomenclature of the Sul-Riograndense Shield, based on interpretation of studies mentioned in this paper. Ages approximate.

\begin{tabular}{|c|c|}
\hline Geological unit & Description \\
\hline Arroio dos Ratos Complex & $\begin{array}{l}\text { Tonalite, trondhjemite, granodiorite, deformed in Dorsal de Canguçu shear. Age } 2.08 \mathrm{Ga} \text {. A } \\
\text { fragment of La Plata Craton inside the Pelotas Batholith, part of the Encantadas Complex. }\end{array}$ \\
\hline Brasiliano Cycle orogens & $\begin{array}{l}\text { The physical manifestation of the Tonian-Ediacaran orogenies; peaks at } 780 \mathrm{Ma}, 660-550 \\
\text { Ma. }\end{array}$ \\
\hline $\begin{array}{l}\text { Brasiliano orogenic cycle }(900- \\
535 \mathrm{Ma})\end{array}$ & $\begin{array}{l}\text { Formed and accreted the juvenile São Gabriel terrane, crustal reworking Pelotas Batholith, } \\
\text { Porongos Complex, Camaquã Basin and granites in the foreland. Developed in the Tonian- } \\
\text { Ediacaran-Cambrian (900-535 Ma), with the La Plata Craton as its basement. }\end{array}$ \\
\hline Brazilian Shield & $\begin{array}{l}\text { Exposed basement of the South American Platform, made up of Archean, Paleoproterozoic, } \\
\text { Mesoproterozoic and Neoproterozoic igneous, metamorphic and sedimentary rocks. It } \\
\text { remained little deformed (a craton) during the Phanerozoic deformation in the Andes. }\end{array}$ \\
\hline Camaquã Basin & $\begin{array}{l}\text { The foreland basin of the Dom Feliciano Belt; flysch at the base and molasse at the top of the } \\
\text { stratigraphy. Age } 601-535 \mathrm{Ma} \text {. }\end{array}$ \\
\hline Capivarita Anorthosite & Massive-type intrusion in the Encruzilhada block, age $1.57 \mathrm{Ga}$. \\
\hline $\begin{array}{l}\text { Cordilheira peraluminous } \\
\text { granites }\end{array}$ & $\begin{array}{l}\text { A suite of Neoproterozoic (660-605 Ma) granitic intrusions aligned with the western border } \\
\text { of the Pelotas Batholith. }\end{array}$ \\
\hline Dom Feliciano Belt & $\begin{array}{l}\text { The Neoproterozoic-Cambrian ( } 900-535 \mathrm{Ma}) \text { mobile belt in Rio Grande do Sul, a portion of } \\
\text { the Brasiliano orogen that extends along the eastern half of South America. }\end{array}$ \\
\hline Dom Feliciano suite & $\begin{array}{l}\text { Monzogranite, syenogranite; age } 595 \text { Ma. Late-orogenic granitic rocks of the Pelotas } \\
\text { Batholith. }\end{array}$ \\
\hline Dom Pedrito structure & $\begin{array}{l}\text { The structure that confines the high aeromagnetometric signal in SW Sul-Riograndense } \\
\text { Shield. Corresponds to the occurrence of granulite and amphibolite facies rocks. }\end{array}$ \\
\hline Encantadas Complex & $\begin{array}{l}\text { Tonalite, trondhjemite, granodiorite, deformed in amphibolite facies. Age } 2.26-2.00 \mathrm{Ga} \text {. It is } \\
\text { a major exposure of the La Plata Craton in the Tijucas terrane. }\end{array}$ \\
\hline Geological provinces & Concept based on surface geology, such as batholith, complex, foreland basin, terrane. \\
\hline Granite intrusions in the foreland & $\begin{array}{l}\text { Neoproterozoic (600-550 Ma) monzogranites, syenogranites and perthite granites intruded in } \\
\text { the São Gabriel and Taquarembó terranes, including the Caçapava, Lavras, Jaguari, Saibro, } \\
\text { Santo Afonso, Santa Rita, Santo Antônio, São Sepé and Cerro da Cria granites. }\end{array}$ \\
\hline La Plata Craton & $\begin{array}{l}\text { Exposed basement in the Sul-Riograndense Shield; remained little deformed during the } \\
\text { Neoproterozoic deformation related to the Brasiliano Cycle of orogenies. Main ages 2.26- } \\
2.00 \mathrm{Ga} \text {, but also } 3.4 \mathrm{Ga}, 2.7 \mathrm{Ga}, 1.7 \mathrm{Ga}, 1.5 \mathrm{Ga} \text {. }\end{array}$ \\
\hline Mudador basalts & $\begin{array}{l}\text { Pillowed and massive basalt flows located south of Caçapava Granite. Possibly part of the } \\
\text { São Gabriel terrane. Age undetermined. }\end{array}$ \\
\hline Paraná Basin & $\begin{array}{l}\text { Large intraplate sedimentary basin (Paleozoic to Cretaceous) capped in a large extension } \\
\text { by Serra Geral Group volcanics; the basin covers the northern, western and part of the } \\
\text { southern portion of the Sul-Riograndense Shield. It extends to the north in Brazil, where the } \\
\text { sedimentary Bauru Group is at the top of the basin (Fernandes and Ribeiro 2015); and to the } \\
\text { west and south into neighboring countries. }\end{array}$ \\
\hline Pelotas batholith & $\begin{array}{l}\text { Orogenic to late-orogenic granitic rocks, including some gneiss and schist remnants; age } 780 \\
\text { Ma, mostly 660-580 Ma. Constitutes the backbone of the Dom Feliciano Belt. }\end{array}$ \\
\hline Pinheiro Machado Complex & $\begin{array}{l}\text { Gneiss, migmatite, tonalite, granodiorite, slivers of metasedimentary rocks; age } 620 \mathrm{Ma} \text {. } \\
\text { Core of orogenic Pelotas Batholith. }\end{array}$ \\
\hline Piquiri syenite & An intrusive body in the Encruzilhada terrane; age $595 \mathrm{Ma}$. \\
\hline Porongos Complex & $\begin{array}{l}\text { Fold and thrust belt of continental schists; greenschist to low amphibolite facies. Youngest } \\
\text { detrital zircon } 580 \mathrm{Ma} \text {. }\end{array}$ \\
\hline Precambrian terrane & $\begin{array}{l}\text { A vague expression that refers to geological units of different composition, structure and age. } \\
\text { Does not include allochtony in the concept. Similar meaning as block, belt and domain. }\end{array}$ \\
\hline Quaternary coastal plain & Extensive coastal plain along the Atlantic Coast of Rio Grande do Sul state. \\
\hline Rio Grande arch & A large structure related to the rifting of Gondwana. \\
\hline
\end{tabular}


TABLE I (continuation)

\begin{tabular}{|c|c|}
\hline Geological unit & Description \\
\hline $\begin{array}{l}\text { Santa Maria Chico Granulitic } \\
\text { Complex }\end{array}$ & $\begin{array}{l}\text { Mafic garnet granulite, trondhjemite, sillimanite gneiss, pyroxenite, spinel lherzolite, iron } \\
\text { formation. Magmatic age } 2.55 \text { and } 2.35 \mathrm{Ga} \text {, metamorphic age } 2.02 \mathrm{Ga} \text {. Main constituent of } \\
\text { Taquarembó terrane. }\end{array}$ \\
\hline Santa Tecla Formation & Tertiary and Quaternary weathering crusts. \\
\hline São Gabriel terrane & $\begin{array}{l}\text { Juvenile } 940-660 \text { Ma orogenic unit, made up of tonalite, trondhjemite, granodiorite, } \\
\text { ophiolite. Oceanic stage of the Brasiliano orogen. }\end{array}$ \\
\hline Serra Geral Group & Tholeiitic basalts and rhyodacites near the top of the Paraná Basin. Age 135 Ma. \\
\hline $\begin{array}{l}\text { Subvertical, transcurrent shear } \\
\text { zones }\end{array}$ & $\begin{array}{l}\text { Subvertical, left-lateral, transcurrent shear zone; e.g., Dorsal de Canguçu, Caçapava, Ibaré } \\
\text { shears. Simplified as "shear" from previous varied designations of "shear zone", "suture" or } \\
\text { "lineament". Age 660-600 Ma. }\end{array}$ \\
\hline Sul-Riograndense Shield & $\begin{array}{l}\text { Local designation of the Brazilian Shield in the state of Rio Grande do Sul; continuous } \\
\text { exposure into Uruguay in the south; age } 2.55 \mathrm{Ga} \text { to } 535 \mathrm{Ma} \text {. }\end{array}$ \\
\hline Supercontinent Gondwana & $\begin{array}{l}\text { Ediacaran agglomeration of continents in the southern hemisphere that left the Brasiliano } \\
\text { orogens as record. }\end{array}$ \\
\hline Taquarembó plateau & Volcanic and sedimentary rocks of the Camaquã basin. \\
\hline Taquarembó terrane & $\begin{array}{l}\text { High-grade metamorphic units situated to the south of the Ibare shear. Largest exposed area } \\
\text { of the La Plata Craton in the Sul-Riograndense Shield. }\end{array}$ \\
\hline Tijucas terrane & $\begin{array}{l}\text { A fold and thrust belt of continental schists (Porongos Complex) containing a strip of } \\
\text { Encantadas Complex and slivers of quartzite, ophiolite and varied Neoproterozoic granitic } \\
\text { rocks. Includes minor } 1.77 \mathrm{Ga} \text { and } 1.57 \mathrm{Ga} \text { granitic and metamorphosed mafic rocks. }\end{array}$ \\
\hline Trans-Amazonian orogenic cycle & Main crust-forming event in the Sul-Riograndense Shield; age $2.26-2.00 \mathrm{Ga}$. \\
\hline Vacacaí Complex & $\begin{array}{l}\text { Volcanic and sedimentary rocks of the São Gabriel terrane, including ophiolites; greenschist } \\
\text { to middle amphibolite facies; age 780-700 Ma. }\end{array}$ \\
\hline Vigia Complex & Tonalite, trondhjemite, granodiorite. Age $1.77 \mathrm{Ga}$. Occurs in the Tijucas terrane. \\
\hline
\end{tabular}

spaced 10,000 m oriented NS and EW. The survey covered $159,789.21 \mathrm{~km}$ of flights. Border regions of the shield were also covered, including strips of the Paleozoic-Mesozoic Paraná Basin to the north, west and south and the Quaternary coastal plain in the east. A Scintrex CS-2 equipment was used for the acquisition of magnetic data. Two equipment were used in two different airplanes for the acquisition of gamma spectrometric data, the Exploranium GR-820 and the Radiation Solutions Inc./RS500 spectrometers. Radar altimeters King 405 and Collins ALT-50 and barometers Fugro/ Enviro were used in different airplanes to obtain the digital terrain model of the shield.

The geophysical magnetic (total magnetic field) and gamma spectrometry (potassium, thorium and uranium channels) data processing was done at LASA PROSPECÇÕES S.A., Rio de Janeiro, involving the application of Oasis Montaj routines, version 7.1.1 (GEOSOFT 2005). Maps were generated in several scales, and also a data bank. This data bank was used at the Geological Survey of Brazil office in Porto Alegre to produce maps of the digital elevation model, the $\mathrm{Th} / \mathrm{K}$ ratio, the total gamma spectrometry, $\mathrm{U}, \mathrm{eTh}, \mathrm{eU}, \mathrm{K}-\mathrm{Th}-\mathrm{U}$, total magnetic field and analytical signal presently presented and interpreted in this paper.

\section{DESCRIPTION OF GEOLOGY}

The study area is indicated in Figure 1 and covers the Sul-Riograndense Shield and surrounding areas. The geology of the shield (inset in Figure 2) has been organized into the Paleoproterozoic La Plata craton fragments and the Neoproterozoic Dom Feliciano Belt (e.g., Hartmann et al. 2000, 2007). The oldest units (e.g., Hartmann et al. 2000, 2007) are the Santa Maria Chico Complex (2.52.0 Ga), the Encantadas Complex (2.3-2.0 Ga), the Arroio dos Ratos Complex $(2.0 \mathrm{Ga})$ and the 
Vigia Complex (1.77 Ga), as well as the Capivarita Anorthosite (1.57 Ga). The younger mobile belt has the Pelotas batholith as a core (e.g., Philipp et al. 2008) along the Atlantic coast and several units in the foreland, including the Porongos Complex, the Camaquã Basin and several granitic plutons (Caçapava, Lavras, Jaguari, Saibro, Santo Afonso, Santa Rita, São Sepé and Cerro da Cria). After cratonization at $535 \mathrm{Ma}$ (Hartmann et al. 2004), the shield was intruded by numerous NW-directed basalt dikes and several small ( 0.5-1.0 m large) alkaline intrusions. The opening of the South Atlantic Ocean at $\sim 112 \mathrm{Ma}$ (Torsvik et al. 2009) generated the major NW-directed Rio Grande arch. The intraplate Paraná Basin (460-66 Ma) covered

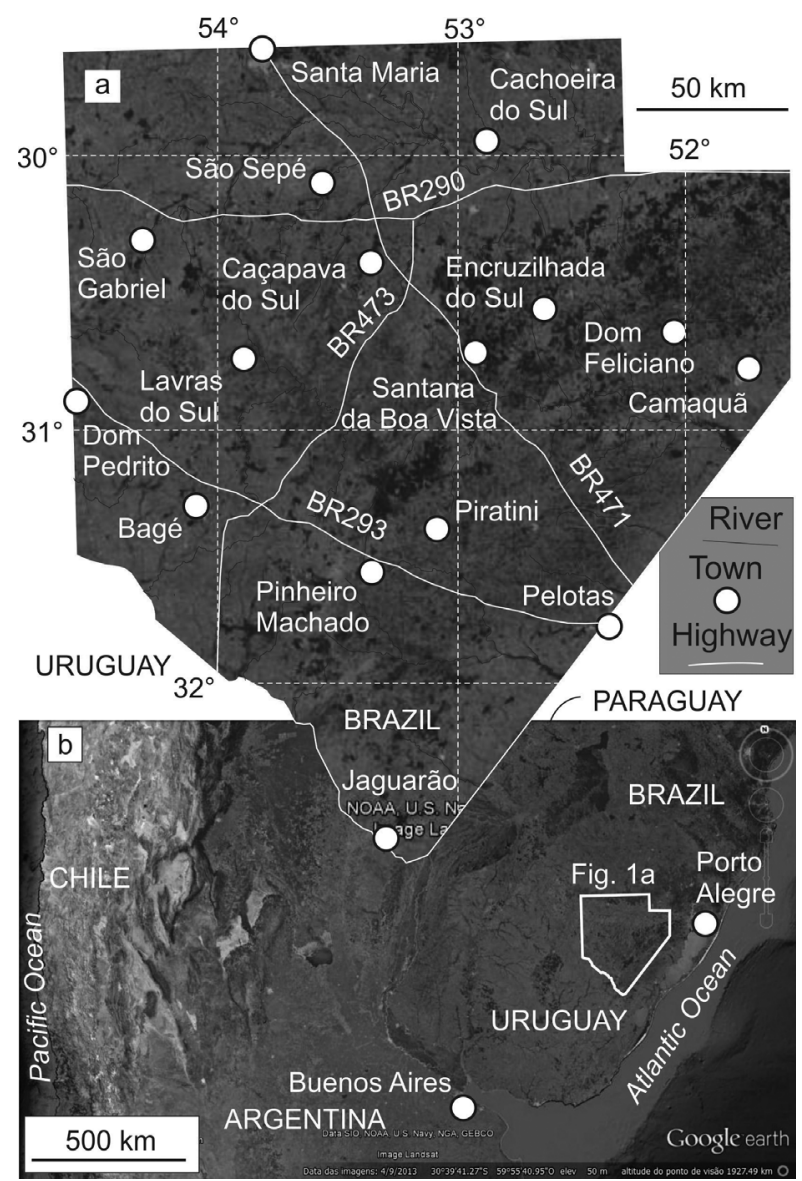

Figure 1 - Location of study area in GoogleEarth satellite images, indicating main geographic references. See the colors in the online version. the shield with sedimentary and volcanic rocks, still marking the western and northern limits of the shield (e.g., Milani et al. 1998, Salgado and Carvalho, 2008.

Pronounced Neoproterozoic, NE-directed shear activity left a strong imprint in the shield (Fernandes and Koester 1999, Bitencourt and Nardi 2000). The Dorsal de Canguçu shear marks the limit between the Tijucas terrane in the center of the shield with the Pelotas batholith in the east and is marked by the intrusion of Cordilheira peraluminous granites (Philipp et al. 2013). Another major terrane boundary is interpreted as the Caçapava shear (Costa 1997, Saalmann et al. 2011). The NW-directed Ibaré shear is the limit between the Taquarembó terrane in the south and the São Gabriel terrane in the north, respectively a Paleoproterozoic, granulite-facies unit and a Neoproterozoic (880-650 Ma), juvenile graniticsedimentary-volcanic unit.

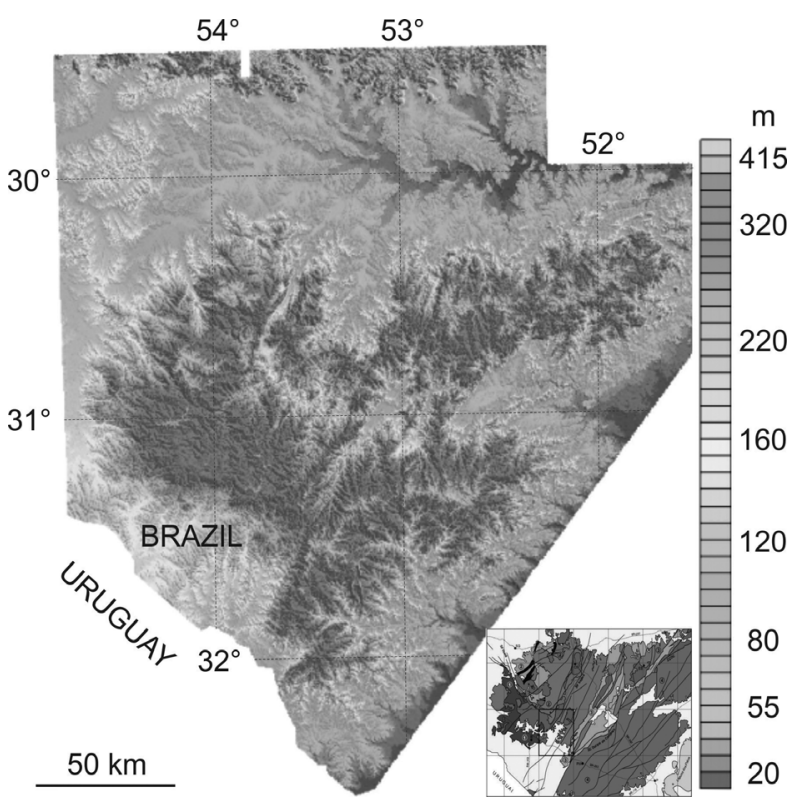

Figure 2 - Digital terrain elevation of study area. Large, red region in the center corresponds to higher elevations of the SulRiograndense Shield. Inset is the geological map of the studied region (Camozzato and Lopes 2012), indicating the major geotectonic units recognized in the shield. For interpretation of the references to color in this figure legend, the reader is referred to the web version of this article. 


\section{RESULTS}

The description of results is focused on each technique used for the investigation. As a consequence, the provinces or their borders suggested for the Sul-Riograndense Shield do not coincide although their limits are similar. Results are presented in the sequence of a GoogleEarth image with the location of towns and highways (Figure 1), the digital terrain elevation (Figure 2), $\mathrm{Th} / \mathrm{K}$ ratio (Figure 3), total gammaspectrometric signal (Figure 4), total $\mathrm{K}+\mathrm{eU}+\mathrm{eTh}$ signal (Figure 5), Dorsal de Canguçu total $\mathrm{K}+\mathrm{eU}+\mathrm{eTh}$ (Figure 6), K content (Figure 7), eU content (Figure 8), eTh content (Figure 9), analytic signal of the aeromagnetic anomaly (Figure 10) and differential reduction to pole (DRTP) (Figure 11). In some aspects, the systematics of result attainment resembles the study of Pedrosa et al. (2015) in Northeastern Brazil using aerogammaspectrometric and aeromagnetometric data from CPRM.

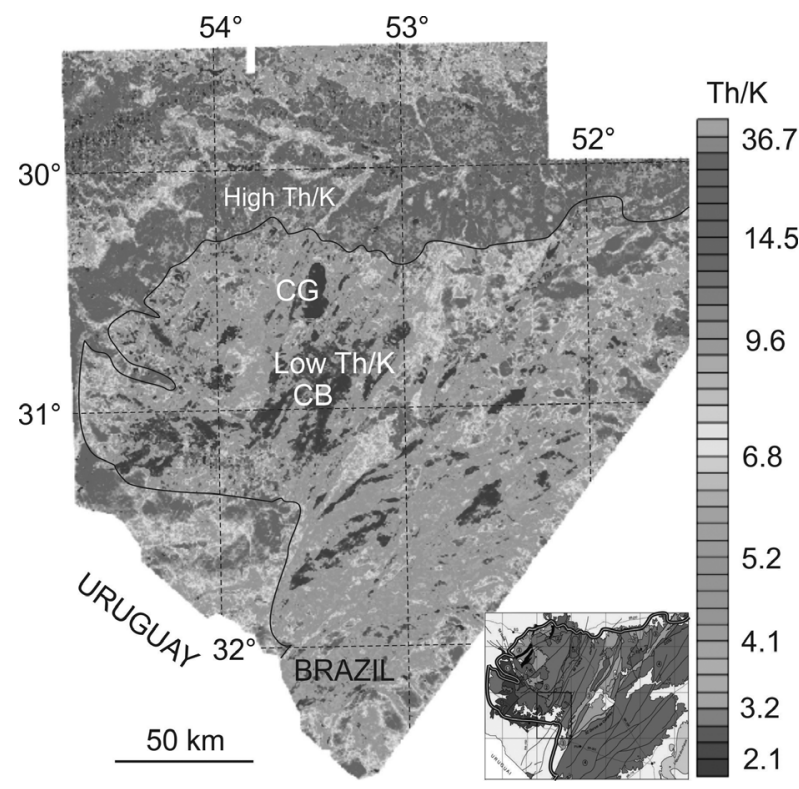

Figure 3 - Map of $\mathrm{Th} / \mathrm{K}$ signal in the study area, indicating in red areas mostly the presence of clay minerals that retain Th. $\mathrm{CG}=$ Caçapava granite, $\mathrm{CB}=$ Camaquã Basin. For interpretation of the references to color in this figure legend, the reader is referred to the web version of this article.

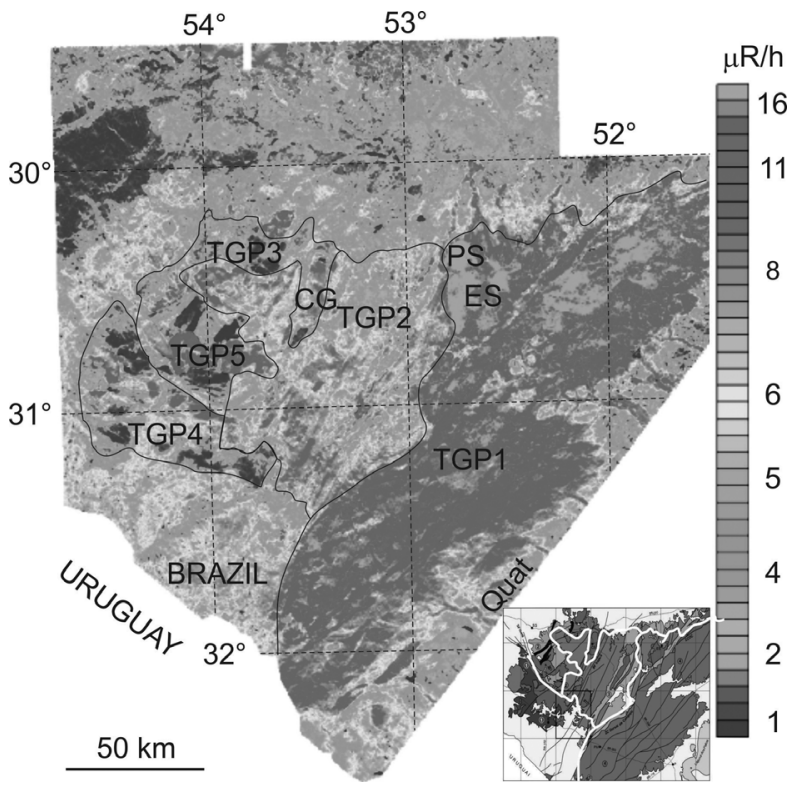

Figure 4 - Identification of major total gamma spectrometry provinces in the Sul-Riograndense Shield (e.g., TGP1). TGP5 $=$ granitic plutons in the foreland. Quat $=$ Quaternary coastal plain, ES = Encruzilhada block, PS = Piquiri syenite. For interpretation of the references to color in this figure legend, the reader is referred to the web version of this article.

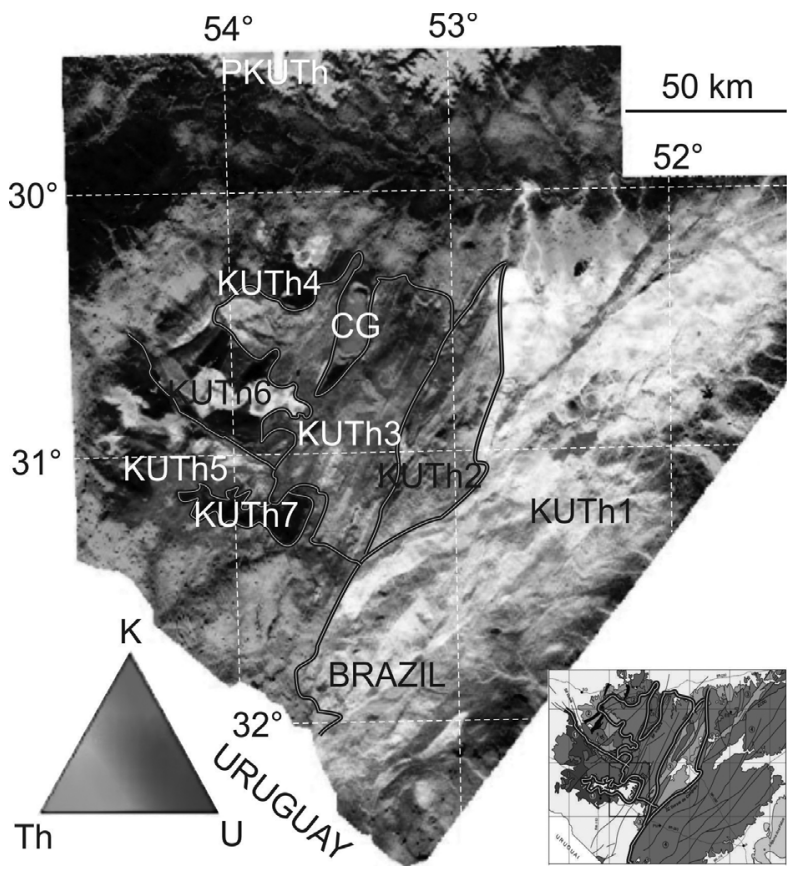

Figure 5 - Total $\mathrm{K}+\mathrm{eU}+\mathrm{eTh}$ provinces, the Sul-Riograndense Shield. Identification of major total $\mathrm{K}+\mathrm{eU}+\mathrm{eTh}$ provinces (e.g., KUTh7). KUTh6 = granitic plutons in the foreland. For interpretation of the references to color in this figure legend, the reader is referred to the web version of this article. 
The digital terrain elevation model is a measure of the topographic expression of the shield and neighboring areas, which is caused by the action of rain, weathering, chemical and detrital transport acting on rocks with variable mineralogical, chemical and structural features. The shield has been exposed at the surface at least

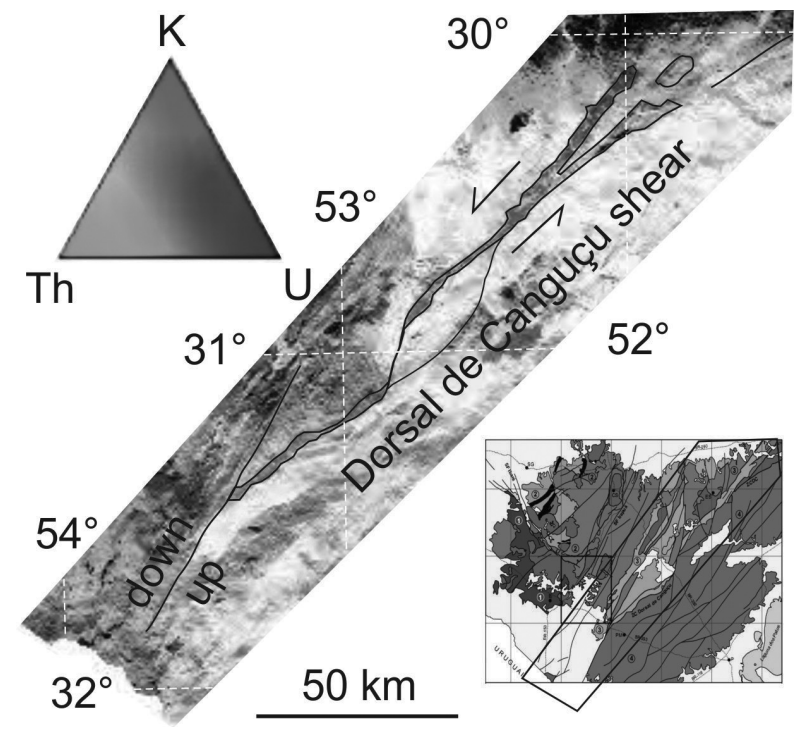

Figure 6 - Selected example of application of total $\mathrm{K}+\mathrm{eU}$ + eTh signal to describe the Dorsal de Canguçu shear. For interpretation of the references to color in this figure legend, the reader is referred to the web version of this article.

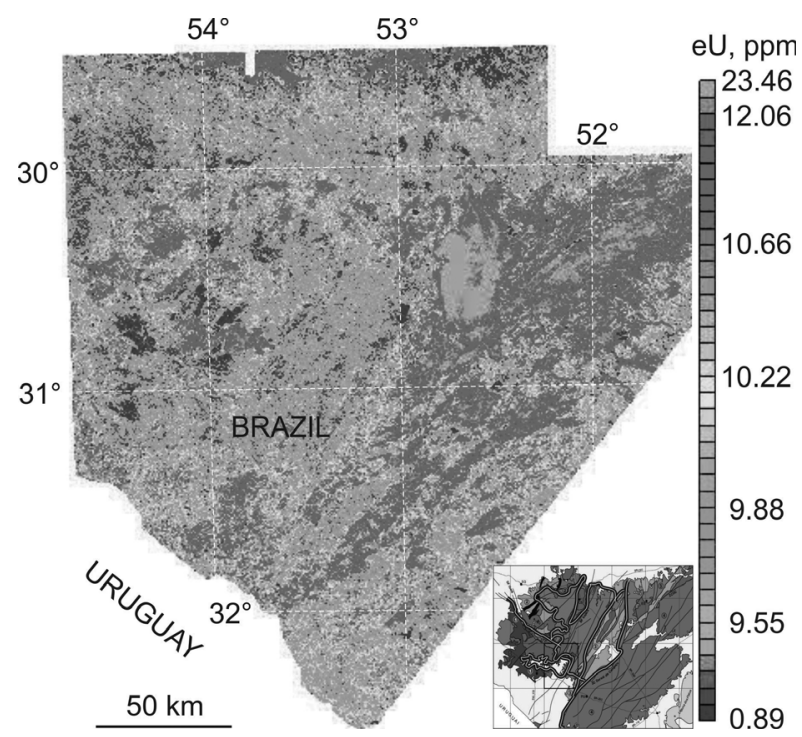

Figure 8 - Map of eU signal over the Sul-Riograndense Shield. For interpretation of the references to color in this figure legend, the reader is referred to the web version of this article. since the Cretaceous, because many feeder dikes of the Serra Geral Group are described in the shield. The $\mathrm{Th} / \mathrm{K}$ ratio is a measure of weathering of the rocks, because $\mathrm{Th}$ is preferentially incorporated and retained by clay minerals. The total gammaspectrometric map is an expression of radioactivity from $\mathrm{K}, \mathrm{U}$ and $\mathrm{Th}$ close to the surface,

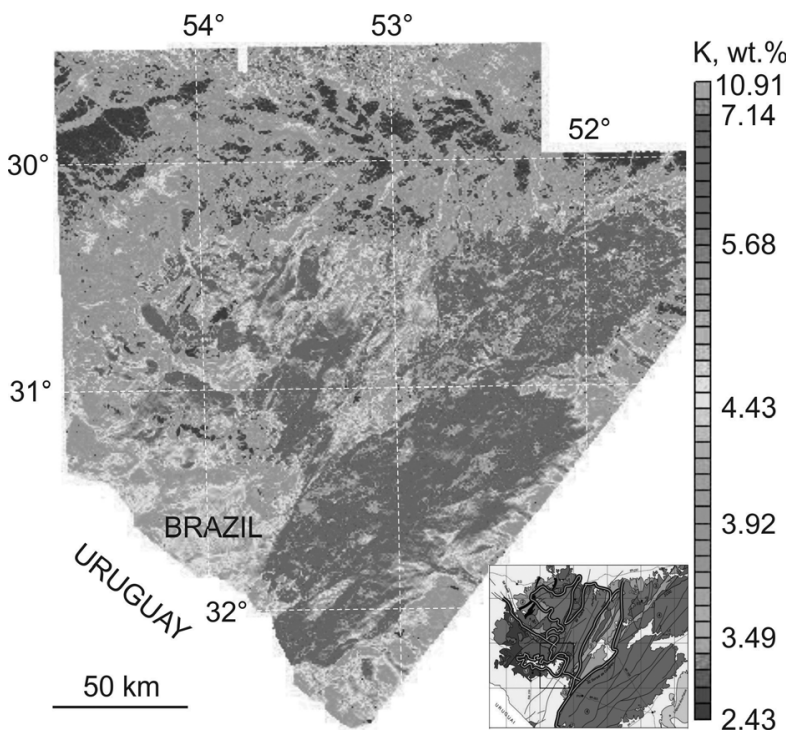

Figure 7 - Total K (\%) signal over the Sul-Riograndense Shield. For interpretation of the references to color in this figure legend, the reader is referred to the web version of this article.

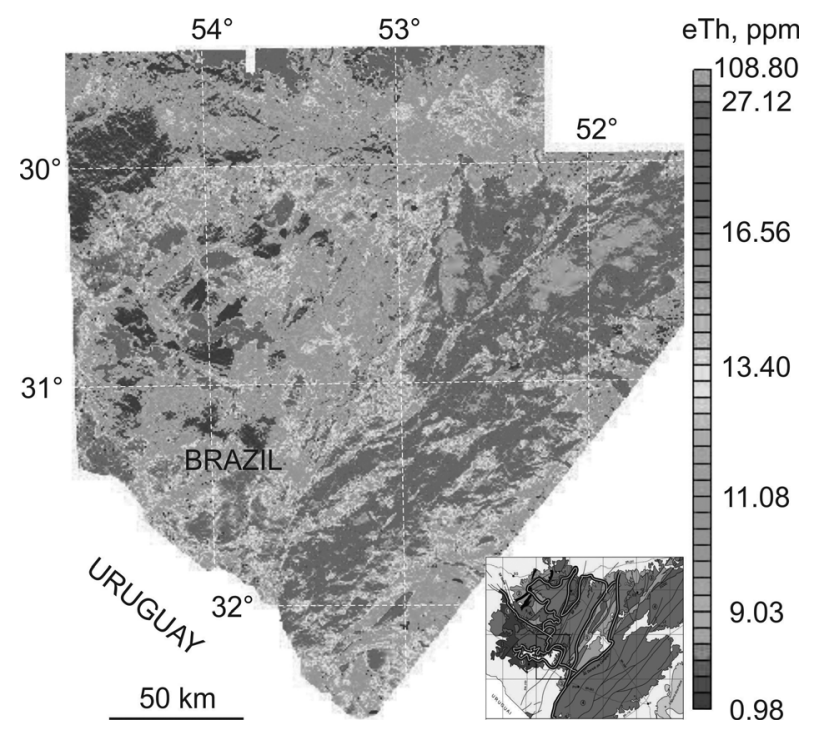

Figure 9 - Map of eTh signal over the Sul-Riograndense Shield. For interpretation of the references to color in this figure legend, the reader is referred to the web version of this article. 


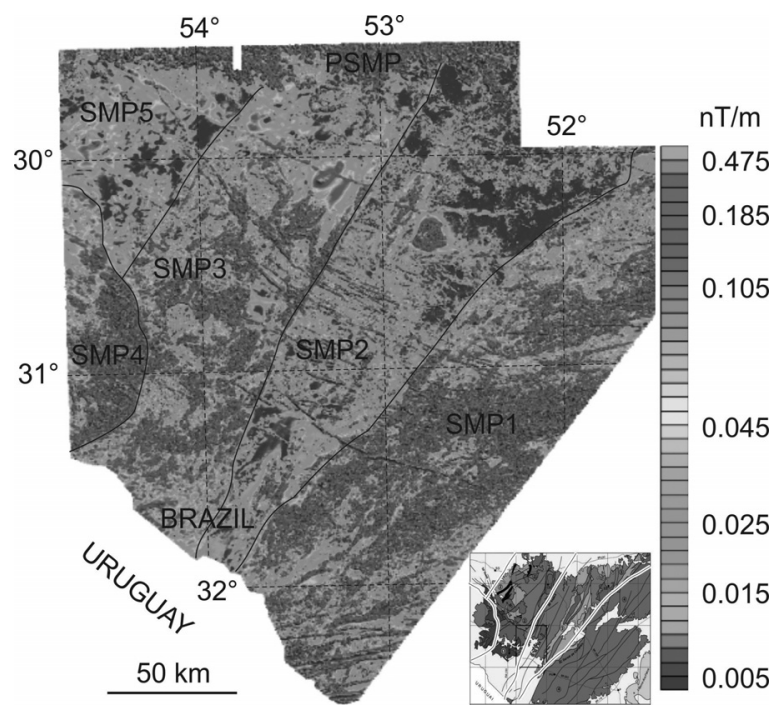

Figure 10 - Map of the analytic signal of the aeromagnetic anomaly of the Sul-Riograndense Shield. Indication of shallow magnetic provinces in the Sul-Riograndense Shield (e.g., SMP1). PSMP = Paraná shallow magnetic province. For interpretation of the references to color in this figure legend, the reader is referred to the web version of this article.

and the K-U-Th map integrates the distribution of radioactivity from the three elements. The analytical signal registers the borders of magnetic bodies at shallow crustal levels whereas the total magnetic field measures properties in the total thickness of the crust.

\section{DIGITAL TERRAIN ELEVATION MODEL}

The highest elevations of the shield (Figure 2) are near $450 \mathrm{~m}$ above sea level (a.s.1.) It is surrounded by subdued topography; along the east, the Quaternary coastal plain has elevation below $50 \mathrm{~m}$, whereas the Paraná Basin sedimentary rocks are at $100 \mathrm{~m}$ elevation at the head of the Jacuí River in the west grading down to $10 \mathrm{~m}$ in the east. In the southern border of the shield, the Paraná Basin rocks are higher near $150 \mathrm{~m}$. To the west of the shield, these sedimentary formations stand at $100 \mathrm{~m}$ elevation. The northern strip of Figure 2 corresponds to the top of the Paraná basin, where the Serra Geral Group rhyodacites are at $450 \mathrm{~m}$ elevation.

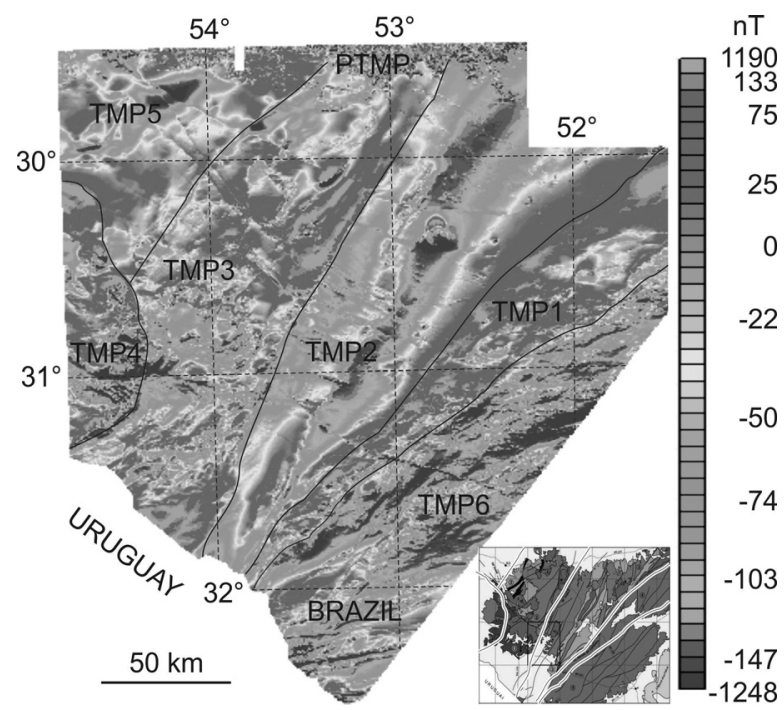

Figure 11 - Differential reduction to pole (DRTP) of the aeromagnetic anomalies over the Sul-Riograndense Shield; intensity of signal is dependant on crust + shallow upper mantle magnetism. Total magnetic provinces indicated (e.g., TMP6). Contact between provinces described in Figure 10 are pasted on this figure for comparison. For interpretation of the references to color in this figure legend, the reader is referred to the web version of this article.

Some features stand out in the digital terrain elevation model, such as the western limit of the Pelotas batholith along the Dorsal de Canguçu shear particularly in the southern part, the Caçapava shear, the southern EW delimitation of the Taquarembó terrane and the Ibare shear. More easily erodible portions of the shield are also low-lying, such as the EW deep incision caused by the Camaquã River through the Pelotas batholith (near $31^{\circ} \mathrm{S}$ ).

\section{Th/K RATIO MAP}

The distribution of the $\mathrm{Th} / \mathrm{K}$ ratio in the SulRiograndense Shield is mostly controlled by soil capacity to retain $\mathrm{Th}$, particularly in clay minerals. This appears readily in high ratio areas of the large EW Paraná Basin strip in the upper part of the figure, opposed to low ratios in the shield. The Caçapava granite (CG in Figure 3) stands out as a low-ratio geological body, as well as other granitic intrusions in several places. The Camaquã Basin sandstones and conglomerates (CB in Figure 3) to the south of Caçapava do Sul also display low $\mathrm{Th} / \mathrm{U}$ ratios. 
GEOLOGY VERSUS TOTAL GAMMA SPECTROMETRIC SIGNAL

Few total rock determinations of $U$ and Th contents are available for the shield and these are listed in Table II. The Pelotas batholith stands out in the gamma spectrometric map (Figure 3) as a 60-km wide NE-trending belt along the coast, and constitutes the Total Gamma Spectrometric Province 1 (TGP1 in Figure 4). It is delimited on the east by the Quaternary coastal plain, but the radioactive signal of the batholith is transported eastwards with detrital sediments. Alluvial deposits appear as high-spectrometry strings along the northern and eastern borders of the batholith, e.g., Camaquã river valley (parallel $31^{\circ}$ ) and small drainage channels.

In the batholith, the signal is strongest in the northern portion. The Encruzilhada terrane has similar intensity to the portion located east of the Dorsal de Canguçu shear (see Figures 5 and 6). To the west of the Pelotas batholith, the Porongos Complex of schists displays intermediate-intensity gamma spectrometry similar to the Camaquã Basin. Both are included in TGP2 province.

Within the western portion of the shield area, there are several regions displaying low gamma

TABLE II

Selected chemical compositions of geological units from the Sul-Riograndense Shield; $(-)=$ not analyzed.

\begin{tabular}{|c|c|c|c|c|}
\hline Geological unit & $\mathrm{SiO}_{2}$, wt. $\%$ & $\mathrm{~K}_{2} \mathrm{O}$, wt.\% & Th, ppm & $\mathrm{U}, \mathrm{ppm}$ \\
\hline \multicolumn{5}{|c|}{ Pelotas batholith } \\
\hline Pinheiro Machado complex ${ }^{3}$ & 62.90 & 2.09 & - & - \\
\hline Dom Feliciano suite ${ }^{3}$ & 71.80 & 3.81 & - & - \\
\hline Encruzilhada do Sul suite ${ }^{3}$ & 71.15 & 5.08 & - & - \\
\hline Viamão suite ${ }^{3}$ & 68.38 & 4.95 & - & - \\
\hline Cordilheira suite, granite $^{4}$ & 75.63 & 4.61 & - & - \\
\hline \multicolumn{5}{|c|}{ Porongos Complex } \\
\hline Metapelite $^{1}$ & 65.56 & 3.56 & 14 & 5 \\
\hline \multicolumn{5}{|c|}{ Encantadas Complex } \\
\hline Tonalite $^{1}$ & 68.70 & 2.33 & 9.1 & 0.3 \\
\hline \multicolumn{5}{|c|}{ Camaquã Basin } \\
\hline Rhyolite $^{5}$ & 73.94 & 4.98 & 12 & 2 \\
\hline Basalt $^{5}$ & 51.70 & 1.64 & 4.6 & 1 \\
\hline \multicolumn{5}{|c|}{ São Gabriel terrane } \\
\hline Metabasalt $^{2}$ & 52.61 & 1.63 & 1.7 & 0.5 \\
\hline Talc schist ${ }^{10}$ & 51.61 & 0.01 & - & - \\
\hline \multicolumn{5}{|c|}{ Taquarembó terrane } \\
\hline Mafic granulite $^{6}$ & $\sim 50$ & 0.5 & - & - \\
\hline Felsic granulite ${ }^{6}$ & $\sim 73$ & 1.0 & - & - \\
\hline \multicolumn{5}{|l|}{ Foreland granites } \\
\hline Lavras-Jaguari $^{7}$ & 73.12 & 4.93 & - & - \\
\hline Santo Afonso ${ }^{9}$ & 64.94 & 4.65 & - & - \\
\hline Saibro $^{9}$ & 72.75 & 5.49 & - & - \\
\hline São Sepé ${ }^{8}$ & 70.45 & 3.97 & - & - \\
\hline $\operatorname{Ramada}^{7}$ & 73.79 & 4.66 & - & - \\
\hline
\end{tabular}

${ }^{1}$ Philipp et al. (2008), ${ }^{2}$ Lopes and Hartmann (2003), ${ }^{3}$ Philipp and Machado (2005), ${ }^{4}$ Nardi and Frantz (1995), ${ }^{5}$ Sommer et al. (2005), ${ }^{6}$ Hartmann (1998), ${ }^{7}$ Nardi and Bonin (1991), ${ }^{8}$ Sartori and Ruegg (1979), ${ }^{9}$ Hartmann and Nardi (1982), ${ }^{10}$ Bitencourt and Hartmann (1984). 
spectrometry and constituting the TGP3 province. These correspond to the distribution of mafic and ultramafic rocks in the São Gabriel terrane and to the low-K (0.5 wt\%; Hartmann 1988) granulites in the Taquarembó terrane. The Mudador basalts and volcaniclastic unit south of Caçapava do Sul (CG in Figure 4) are also low, similar to the São Gabriel terrane. Granulites in the Taquarembó terrane and some gneiss exposures (e.g., Vigia Complex) have low signal and make up the TGP4 province.

Granitic plutons of TGP5 stand out in red in the foreland. The highest gamma spectrometry is in the Lavras-Jaguari plutons (below TGP5 in Figure 4), followed by several plutons, variously named São Sepé, Cerro da Cria, Santo Afonso-Saibro and portions of the Caçapava Granite. The Santa Rita Granite has the lowest signal among the plutons, similar to most of the Caçapava Granite.

The image also displays in the northwestern corner $\left(31^{\circ} \mathrm{S}\right)$ a region in the Paraná Basin with very low total gamma spectrometry. Detritus from this low spreads downstream along the Rio Jacuí valley.

GEOLOGY VERSUS K+eU+eTh

In the $\mathrm{K}+\mathrm{eU}+\mathrm{eTh}$ image (Figure 5), the main terranes of the shield show distinct colors and taints that resemble a geological map. The Pelotas batholith constitutes the total $\mathrm{K}+\mathrm{eU}+\mathrm{eTh}$ province 1 (KUTh1 in Figure 5) and has a bright signal due to richness in all three elements, including the Encruzilhada block of Jost and Hartmann (1984). It displays different hues internally, corresponding to different granitic intrusions and to shear zones. Immediately to the west, the Porongos Complex (KUTh2) appears similar but richer in $\mathrm{U}$; the Encantadas Complex on the western portion of this province appears red. The Camaquã Basin sedimentary rocks are the KUTh3 province and have a distinct brown hue, possibly due to enrichment in both $\mathrm{K}$ and $\mathrm{U}$. The mafic-ultramafic Vacacaí Complex in the São Gabriel terrane (KUTh4 province) is dark, nearly black, similar to the granulites of the Taquarembó terrane (KUTh5 province), due to very low contents of the three elements. KUTh6 is the province that includes granitic plutons intruded into the foreland (e.g., Lavras-Jaguari granite below symbol KUTh6). The Ediacaran granite plutons are bright; for instance, the Caçapava Granite (CG in Figure 5) is red, due to high $\mathrm{K}$ content. The Lavras-Jaguari granite is bright, similar to the Pelotas batholith. Another dark region corresponds to the Santa Tecla Formation (KUTh7 province) to the north of Bagé. The dark nearly black grades into blue at the rims of the exposures (rich in U).

Paraná Basin sedimentary rocks display light blue $(\mathrm{U}+\mathrm{Th}$, low $\mathrm{K})$ color at the base of the stratigraphy, followed by a dark belt (low K-U$\mathrm{Th}$ ) and then a unit of variously tainted portions of blue on the east evolving to dark nearly black in the west. The overlying Serra Geral Group rocks have blue color ( $\mathrm{U}+\mathrm{Th}$, low $\mathrm{K})$.

We selected the Dorsal de Canguçu shear contained in the KeUeTh1 province in its northeastern portion and along the contact with KeUeTh2 in the southern portion to exemplify the utility of the map of $\mathrm{K}+\mathrm{eU}+\mathrm{eTh}$ signal (Figure $6)$. The shear zone has distinctive purple color (K $+\mathrm{U}$, little Th) and can be easily traced. The leftlateral displacement abuts against a normal fault in the southwest where the western block was downthrown, thus leading to the present exposure of Paraná Basin sedimentary rocks directly in contact with the Pelotas batholith.

\section{GEOLOGY VERSUS K, eU AND eTh}

The content of $\mathrm{K}$ is rather high in the entire shield and particularly in the Pelotas batholith (Figure 7). The Paraná Basin sedimentary rocks are low in comparison with the shield. Low-K portions of the shield present in the western region correspond to mafic-ultramafic rocks in the São Gabriel terrane and to granulites and gneisses in the Taquarembó terrane. The eU (Figure 8) and eTh (Figure 9) maps 
are similar although differences are present in detail. For instance, province KUTh7 corresponds to the Santa Tecla Formation (Figure 5) and has high $\mathrm{K}$ but low eU and low eTh (Figures 8 and 9).

\section{Geology Versus Total MAGNetic FiELD}

Aeromagnetic data have been widely used to identify magnetic anomalies in the Earth magnetic field caused by magnetic minerals in the rocks (e.g., Nabighian et al. 2005, Pilkington 2007, Rajaram and Anand 2014). Anomalies observed in maps and images can be interpreted in terms of geology. In this work, magnetic information was used to differentiate the rock types based on the magnetic susceptibility and remanent magnetization of the rocks at the surface.

The analysis of airborne magnetic data through the analytic signal (Figure 10) amplitude of the total magnetic field (e.g., Nabighian 1972, 1974, Roest et al. 1992) resulted in the identification and classification of five Shallow Magnetic Provinces (SMP1, SMP2, SMP3, SMP4 and SMP5). This arrangement contributes to the description of the magnetic signature of different bodies of contrasting geological units (Milligan and Gunn 1997). The largest magnetic values occur in SMP1, SMP3, and SMP4. The SMP1 region represents the Neoproterozoic granitic magmatism of the Pelotas batholith. The SMP3 province is the volcanosedimentary sequence of the São Gabriel terrane. Province SMP4 is a circular structure that includes most of the Santa Maria Chico Granulitic Complex (age 2.5-2.0 Ga) in the Taquarembó terrane and also the Taquarembó plateau of mostly volcanic rocks (550 Ma). The low magnetic values observed in SMP2 are associated with the metavolcanic sedimentary rocks of the Tijucas terrane. The same low values are found in SMP5 of the São Gabriel terrane.

The analysis of total magnetic field data results in the identification in the Sul-Riograndense Shield (Figure 11) of six Total Magnetic Provinces (TMP1, TMP2, TMP3, TMP4, TMP5, TMP6). These provinces (Figure 11) have magnetic anomalies from -1248 to $1190 \mathrm{nT}$. Low magnetic intensity is registered in TMP2 and TMP6 provinces. High magnetic values occur in TMP1, TMP3, TMP4, and TMP5 provinces.

\section{GEOLOGY VERSUS ANALYTIC SIGNAL AND TOTAL} MAGNETIC SignAL

Five shallow magnetic provinces (SMP1, SMP2, SMP3, SMP4, SMP5) are identified (Figure 10) in the shield and one in the volcanic cover (PSMP), based on the analytic signal. The entire Pelotas batholith (SMP1) has high analytic signal and is bordered on the west by a low signal province (SMP2), which is the locus of the Encruzilhada terrane and the Tijucas terrane. Province SMP3 occurs to the west of the Caçapava shear and includes all granitic plutons and part of the Camaquã Basin in the foreland. It is delimited to the NW by the presence of a low analytic signal province (SMP5), mostly covered by Paraná Basin sedimentary rocks. Province SMP3 is delimited on its SW border by a circular high analytic signal (SMP4). Paraná volcanic province basalts and rhyodacites (PSMP) have high signal and occur in the north of the surveyed area, an indication that shallow magnetic bodies are better registered in the analytic signal image. The Piquiri syenite (PS in Figure 4) stands as a high, in strong contrast with the low analytic signal in the remaining portion of the Encruzilhada block (ES in Figure 4).

Total magnetometric provinces are designated TMP1, TMP2, TMP3, TMP4, TMP5 and TMP6 (Figure 11). The limits of SMP of Figure 10 were copied and pasted in the same geographic position in Figure 11 displaying a near-coincidence of position in the two displays of magnetic signals. The northern half of the Pelotas batholith (TMP1) has high magnetic signal, but the southern half displays a low signal, so it is designated TMP6. TMP5 has high total magnetic signal (Figure 11), in contrast with low analytic signal (Figure 10). All 
other TMP coincide in relative intensity of magnetic signal in both Figures 10 and 11. The Piquiri syenite (PS in Figure 4) also stands as a high within the Encruzilhada terrane low (Figure 11).

The half-circular region demarcated as SMP4 (Figure 10) is also marked as TMP4 in Figure 11 in the extreme west of the shield between $30.10^{\circ} \mathrm{S}$ and $31.40^{\circ} \mathrm{S}$, with NS diameter of $150 \mathrm{~km}$ and EW radius of $30-50 \mathrm{~km}$. TMP4 displays a strong magnetic disturbance near $31^{\circ} \mathrm{S}$ that continues to the east through TMP3, TMP2 and to the ESE into TMP6.

A set of NW-NWW directed basaltic dikes is displayed in Figure 10 and less-markedly in Figure 11, bending to EW and NEE direction in SMP2 and in SMP1 (Pelotas batholith). A few dikes are seen to extend across the entire area of the shield and continuing below the sedimentary rocks of the Paraná Basin. A few ENE dikes are marked in the southernmost part of the shield. In the northern portion of the image (Figure 10), a few dikes are registered below the sedimentary rocks of the Paraná Basin.

\section{INTERPRETATION}

No attempt is made here to propose a unique model of tectonic provinces for the shield, because each technique yields particular results in the images. The reader is directed to focus on his interest and thus benefit from this study. Because very few determinations of $U$ and $T h$ contents were made in rocks from the shield, this is also a contribution to the distribution of these elements in the surveyed area.

We do not attempt to interpret the relative positions of the provinces before the main tectonic events, namely the Trans-Amazonian orogenic cycle (2.25-2.00 Ga) and the Brasiliano orogenic cycle (900-535 Ma). This is due to the lack of indicators of extent of movement in these Precambrian terranes. New studies may allow in the future the establishment of relative allochtony for some of the provinces and consequently the collage history of the shield. Allochtony is to be expected because of the presence of large, wide shear zones, which may have caused the lateral displacement of blocks; e.g., the left-lateral Dorsal de Canguçu shear. Some of the features of the total magnetic field, particularly the upper mantle component, may be due to the splitting of supercontinent Gondwana into South America and Africa.

We propose the subdivision of the SulRiograndense Shield into several provinces for each study technique used, all part of the Dom Feliciano Belt of Ediacaran age (Brasiliano Cycle orogens) and its Paleoproterozoic fragmented basement (La Plata Craton). Provinces based on surface geology are the Pelotas batholith, the Porongos Complex, the Camaquã foreland Basin, the São Gabriel juvenile terrane, the Taquarembó terrane and the granitic plutons intruded into the foreland (Caçapava, Lavras-Jaguari, Santo Afonso, Saibro, Cerro da Cria and São Sepé Granites). Volcanic and sedimentary rocks coeval with the granitic plutons are part of the Camaquã Basin. Some selected aspects are commented below.

The Encruzilhada terrane (ES in Figure 4) belongs to the same crustal province as the Pelotas batholith (PB in Figure 4) from the total gamma spectrometric signal (TGP1), total $\mathrm{K}+\mathrm{eU}+\mathrm{eTh}$ (KUTh1 in Figure 5), and also K (Figure 7), eU (Figure 8) and eTh (Figure 9). This contributes to the debate about the significance of the Encruzilhada block (e.g., Jost and Hartmann 1984), because Soliani (1986) proposed that the two portions of the batholith are similar and part of the same batholith. We conclude that the Encruzilhada terrane is an integral part of the Pelotas batholith based on surface geology. But the information given by aeromagnetometry is strongly contrasting with this observation.

Both shallow and total crustal aeromagnetometry indicate (Figures 10 and 11) that the 
Encruzilhada terrane (SMP2, TMP2) is not part of the main structure of the Pelotas batholith (SMP1, TMP1). They constitute two different crustal terranes in the shield.

The provinces suggested from the total magnetic signal have variable surficial expression but are significant for the understanding of the crustal structure of the shield. A novel feature presently described is the half circle in the SW portion of the shield and extending under the Paraná sedimentary basin; the circle may complete to the west of the surveyed area. This is an improvement of the previous suggestion (Costa 1997, Fernandes et al. 1995b) of the presence of a major linear suture in that region. The circular magnetic high (SMP4, TMP4; Figures 10 and 11) is here designated the Dom Pedrito structure, because the town of Dom Pedrito is located inside the structure. It is a shallow structure, because it is more pronounced in the analytical signal image (Figure 10) than in the total magnetic field image (Figure 11).

The cause of strong disturbance of the Dom Pedrito structure along $31^{\circ} \mathrm{S}$ is related to less magnetic rocks at great depth in the crust, because the disturbance is more pronounced in Figure 11 (TMP4) than in Figure 10 (SMP4). The circular is most likely related to the presence of the Santa Maria Chico Granulitic Complex.

All granitic plutons and most volcanic rocks in the foreland are concentrated in province SMP3 (coincident with TMP3). This is of major significance for the Ediacaran evolution of the shield.

The aeromagnetometric signal also yields a valuable information regarding the geology of the Piquiri syenite (PS in Figure 4). This igneous body is part of the Encruzilhada block in aerogammaspectrometric images (Figures 4, 5, 7, 8,9 ) but stands apart as a high in the magnetometric images (Figures 10,11). The syenite is thus compatible with a deeply rooted intrusive body possibly originating in the mantle. Magmatic studies have indicated the presence of high pressure minerals in the syenite, formed at mantle pressures (Nardi et al. 2007).

The strongest gamma signal in the northern portion of the Pelotas batholith compared to the southern portion is due to the higher contents of $\mathrm{K}, \mathrm{U}$ and $\mathrm{Th}$ in the Dom Feliciano granitic suite than in the tonalitic-granitic Pinheiro Machado Complex. Smaller, high-intensity portions in the south are due to the presence of younger intrusive granites of the Dom Feliciano suite.

A $50 \mathrm{~km}$ large region of very-low gamma spectrometric signal (Figure 4) occurs in the extreme NW of the area covered by the survey, and corresponds to sedimentary rocks of the Paraná Basin. This low spreads for a long distance (150 $\mathrm{km}$ ) downstream along the Jacuí River alluvial sediments and actually to the extreme E of the map near Porto Alegre. The high signal intensity in the extreme north is caused by the rhyodacites of the Serra Geral Group, which overlie basalts in this southernmost border of the plateau.

We have thus described the main geological, gamma spectrometric and magnetometric provinces of the Sul-Riograndense Shield. Each province is homogeneous overall but has large internal variations in the register, corresponding to specific targets for future investigations.

\section{CONCLUSIONS}

Most significant conclusions are reached from this study of the geology of the Sul-Riograndense Shield integrated with a modern aerogammaspectrometric and aeromagnetometric survey. The major structures and the traditional geological division of the shield into western, central and eastern domains are well displayed by the data, including the division into a São Gabriel terrane and a Taquarembó terrane in the west. The Pelotas batholith is highlighted as a fairly homogeneous high in the gamma spectrometric map, as are the granitic plutons in the western 
foreland. In strong contrast, both the juvenile São Gabriel terrane and the granulite-facies Taquarembó terrane display low values. The Camaquã Basin has medium values of gammaspectrometry. We do not attempt to establish a unique division of the shield into provinces that incorporates all the techniques used, because this division is only possible for each technique, as done here.

The magnetic signal is highly variable by provinces and is a result of integrated magnetism from upper mantle and crustal sources. This suggests the presence of lithospheric blocks in the shield. The Caçapava shear and a few others stand out in all investigation methods. The Encruzilhada terrane is seen to be part of the Pelotas batholith in the gamma spectrometric map. But it is part of the central domain of the shield as a low-magnetic lithospheric province. The Piquiri syenite has deep roots in the crust and possibly in the mantle. A 150 $\mathrm{km}$ large circular magnetometric high forms the Dom Pedrito structure in the extreme west of the shield, coincident with the presence of granulites and was strongly disturbed magnetically in a transgressive event.

This integrated study deepensourunderstanding of the geology of the shield and permits a projection of further developments in geological modeling and in the search for ore deposits. Heterogeneities within the larger homogeneous provinces deserve additional investigation. The description of structures here made allows a recommendation for additional studies, including drilling, because circular structures tend to be most significant both for science and ore deposit prospection.

\section{ACKNOWLEDGMENTS}

This paper is the result of integrated scientific effort by researchers at Universidade Federal do Rio Grande do Sul (UFRGS) and at Serviço Geológico do Brasil (CPRM). Financial support was obtained from Conselho Nacional do Desenvolvimento
Científico e Tecnológico (CNPq), Edital Universal, grant number 479555/2012-5. JFS acknowledges Fundação de Amparo à Pesquisa do Estado do Rio Grande do Sul (FAPERGS) for financial support through grant 2329-2551/14-1. The aerogeophysical survey was covered financially by the Brazilian Government through the Geological Survey of Brasil and contracted with LASA PROSPECÇÕES S.A. We acknowledge two journal reviewers for their contributions, which led to significant improvement of the paper.

\section{RESUMO}

Uma integração da geologia, aerogamaespectrometria e aeromagnetometria do Escudo Sul-Riograndense é permitida pelo estágio avançado de entendimento da geologia e geocronologia da porção sul do Escudo Brasileiro e um levantamento aerogeofísico de 2010. Raios gama são registrados a partir de rochas próximas à superfície e descrevem, portanto, a distribuição das principais unidades no escudo, tal como o Batólito Pelotas, o terreno juvenil São Gabriel, o terreno Taquarembó de fácies granulito e anfibolito e as numerosas intrusões graníticas no antepaís. Grandes estruturas também são observadas, como a zona de cisalhamento Dorsal de Canguçu. Sinais magnetométricos registram composições próximas à superfície (sinal analítico) e composição total da crosta (sinal magnetométrico total), de forma que sua variação, conforme medido, indica estruturas rasas ou crustais integrais. A zona de cisalhamento de Caçapava está marcada de forma nítida em todas as imagens, assim como o baixo magnético na porção central N-S do escudo. Estas observações integradas levam ao aprofundamento do entendimento das grandes e também de algumas estruturas detalhadas do Escudo Sul-Riograndense, algumas a serem correlacionadas com a geologia de campo em futuros estudos. Muito significativa é a presença de diferentes províncias e seus limites, na dependência do método usado para a aquisição dos dados - geologia, aerogamaespectrometria ou aeromagnetometria.

Palavras-chave: Aerogamaespectrometria, aeromagnetometria, províncias aeromagnetométricas, províncias aerogamaespectrométricas, Escudo Sul-Riograndense. 


\section{REFERENCES}

BASEI MAS, SIGA JR O, MASQUELIN H, HARARA OM, REIS Neto JM AND PRECiOzZI F. 2000. The Dom Feliciano Belt of Brazil and Uruguay and its Foreland Domain, the Rio de la Plata Craton. Framework, tectonic evolution and correlation with similar provinces of southwestern Africa. In: Cordani UG, Milani EJ, Tomaz A and Campos DA(Eds), Tectonic evolution of South America. $31^{\text {st }}$ International Geological Congress, Rio de Janeiro, Sociedade Brasileira de Geologia, Rio de Janeiro, p. 311-334.

BITENCOURT MF AND HARTMANN LA. 1984. Reconhecimento geoquímico dos xistos magnesianos da região do Passo Feio, Caçapava do Sul - RS. Anais do $33^{\circ}$ Congresso Brasileiro de Geologia, Rio de Janeiro, p. 2607-2614.

BITENCOURT MF AND NARDI LVS. 2000. Tectonic setting and sources of magmatism related to the southern Brazilian shear Belt. Rev Brasil Geociências 30: 186-189.

BIZZI LA, SCHOBBENHAUS C, VIDOTTI RM AND GONÇALVES JH (Eds). 2003. Geologia, tectônica e recursos minerais do Brasil: texto, mapas \& SIG. Brasília, Serviço Geológico do Brasil, CPRM, Ministério de Minas e Energia, Secretaria de Minas e Metalurgia.

CAMOZZATO E AND Lopes RC. 2012. Mapa geológico da Folha Hulha Negra (SH.22-Y-C-I), Rio Grande do Sul. CPRM (Companhia de Pesquisa de Recursos Minerais, Serviço Geológico do Brasil).

CAMOzZATo E, PHILIPP RP AND CHEMALE JR F. 2013. Idades estaterianas e calimianas no domo da Vigia: Complexos Vigia e Porongos, metagranito Seival e anfibolito Tupi Silveira, Bagé, RS. In: XIV Simpósio Nacional de Estudos Tectônicos, Cuiabá, Sociedade Brasileira de Geologia, CD ROM, 1 página.

CHEMALE JR F. 2000. Evolução Geológica do Escudo Sul-RioGrandense. In: Holz M and De Ros LF (Eds), Geologia do Rio Grande do Sul. Porto Alegre, Brazil. Editora UFRGS, p. 13-52.

Chemale JR F, HARTMANn LA AND SIlva LC. 1995a. Stratigraphy and tectonism of the Precambrian to Early Paleozoic units in southern Brazil and Uruguay-excursion guidebook. Acta Geol Leopold 42(XVIII): 5-117.

Chemale JR F, Hartmann LA AND Silva LC. 1995 b. Stratigraphy and tectonism of the Brasiliano Cycle in southern Brazil. Commun Geol Survey Namibia 10: 51166.

Chemale JR F, PHILIPP RP, DUSSIN I, Formoso ML, KAWASHITA K AND BERTOTTI AL. 2011. Lu-Hf and U-Pb age determination of the Capivarita Anorthosite, Dom Feliciano belt, RS, Brazil. Prec Res 186: 117-126.

CostA AFU. 1997. Teste de modelagem geofísica da estruturação das Associações Litotectônicas Pré-Cambrianas no Escudo Sul-Rio-Grandense. PhD thesis, Universidade Federal do Rio Grande do Sul, Porto Alegre, 291 p.
COSTA AFU, FERNANDES LAD, SHUKOWSKY W, NARDI LVS AND BITENCOURT MF. 1995. Teste dos modelos tectônicos e de posicionamento do Complexo Granítico de Caçapava do Sul através de estudos de modelagem gravimétrica 3-D. Rev Bras Geofis 13: 91-101.

COSTA AFU AND RAMGRAB GE. 1989. Lineamento Jaguarão - Caracterização aeromagnética. Rev Bras Geoc 7: 41-45.

CPRM - SERVIÇO GEOLÓGICO DO BRASIL. 2010. Projeto Aerogeofísico Escudo do Rio Grande do Sul. LASA PROSPECÇÕES S.A., Relatório Técnico, 260 p.

FERNANDES LA AND RIBEIRO CMM. 2015. Evolution and palaeoenvironment of the Bauru Basin (Upper Cretaceous, Brazil). J South Am Earth Sci 61: 71-90.

FERNANDES LAD AND KOESTER E. 1999. The Neoproterozoic Dorsal de Canguçu strike-slip shear zone: its nature and role in the tectonic evolution of southern Brazil. J Afr Earth Sci 29: 3-24.

FERnANDES LAD, MENEGAT R, COSTA AFU, KoEster E, PORCHER CC, TOMMASI A, KRAEMER G, RAMGRAB GE AND CAMOZZATO E. 1995a. Evolução tectônica do Cinturão Dom Feliciano no Escudo Sul-Rio-Grandense: Parte I - Uma contribuição a partir do registro geológico. Rev Bras Geoc 25: 351-374.

FERnANDES LAD, MENEGAT R, COSTA AFU, Koester E, PORCHER CC, TOMMASI A, KRAEMER G, RAMGRAB GE AND CAMOZZATO E. 1995b. Evolução tectônica do Cinturão Dom Feliciano no Escudo Sul-Rio-Grandense: Parte II - Uma contribuição a partir das assinaturas geofísicas. Rev Bras Geoc 25: 375-384.

FERNANDES LAD, TOMMASI A AND PORCHER CC. 1992. Deformation patterns in the southern Brazilian branch of the Dom Feliciano Belt: a reappraisal. J South Am Earth Sci 5: 77-96.

Fragoso-CÉSAR ARS, FIgUEIREDO MCH, SOLIANI JR E AND FACCINI UF. 1986. O Batólito Pelotas (Proterozóico Superior/Eo-Paleozóico) no Escudo do Rio Grande do Sul. In: Congresso Brasileiro de Geologia, Goiânia, Anais, Soc Bras Geol 3: 1322-1342.

FRANTZ JC AND BOTELHO NF. 2000. Neoproterozoic granitic magmatism and evolution of the eastern Dom Feliciano belt in southernmost Brazil: A tectonic model. Gondwana Res 3: 7-19.

FrantZ JC, MCNAUGHTON NJ, MARQUES JC, HARTMANN LA, BOTELHO NF AND CARAVACA G. 2003. SHRIMP $\mathrm{U}-\mathrm{Pb}$ zircon ages of granitoids from southernmost Brazil: Constraints on the temporal evolution of the Dorsal de Canguçu transcurrent shear zone and the eastern Dom Feliciano Belt. Short papers IV South American Symposium on Isotope Geology, p. 174-177.

GEOSOFT. 2005. Sharpening using interactive reweighting inversion, Oasis Montaj best practice guide, www. geosoft.com.

GREGORY TR, BITENCOURT MF, NARDI LVS, FLORISBAL LM AND CHEMALE JR F. 2015. Geochronological data from TTG-type rock associations of the Arroio dos 
Ratos Complex and implications for crustal evolution of southernmost Brazil in Paleoproterozoic times. Jour S Amer Earth Sci 57: 49-60.

Gross AOMS, PORCHER CC, FERNANDES LAD AND KOESTER E. 2006. Neoproterozoic low-pressure/hightemperature collisional metamorphic evolution in the Várzea do Capivarita Metamorphic Suite, SE Brazil: Thermobarometric and Sm/Nd evidence. Precamb Res 147: 41-64.

HARTMANN LA. 1988. Geoquímica de terras raras e geotermobarometria de granulitos de Dom Pedrito e Luis Alves, no extremo Sul do Brasil. Geoch Bras 2: 1-14.

HARTMANN LA. 1998. Deepest exposed crust of Brazilgeochemistry of Paleoproterozoic depleted Santa Maria Chico granulites. Gondwana Res 1: 331-341.

HARTMANN LA. 2002. The Mesoproterozoic supercontinent Atlantica in the Brazilian shield-review of geological and $\mathrm{U}-\mathrm{Pb}$ zircon and $\mathrm{Sm}-\mathrm{Nd}$ isotopic evidence. Gondw Res 5: 157-163.

HARTMANN LA, CAMPAL N, SANTOS JOS, MCNAUGHTON NJ, BOSSI J, SCHIPILOV A AND LAFON JM. 2001. Archean crust in the Rio de La Plata Craton, Uruguay - SHRIMP $\mathrm{U}-\mathrm{Pb}$ zircon reconnaissance geochronology: Jour S Amer Earth Sci 14: 557-570.

HARTMANN LA, CHEMALE JR F AND PhilipP RP. 2007. Evolução geotectônica do Rio Grande do Sul no PréCambriano. In: Iannuzzi R and Frantz JC (Eds), 50 Anos de Geologia, Instituto de Geociências, Contribuições. Porto Alegre, Comunicação e Identidade, p. 97-123.

HARTMANN LA, LEITE JAD, MCNAUGHTON NJ AND SANTOS JOS. 1999. Deepest exposed crust of BrazilSHRIMP establishes three events. Geology 27: 947-950.

HARTMANN LA, LEITE JAD, SilVA LC, REMUS MVD, MCNAUGHTON NJ, GROVES DI, FLETCHER IR, SANTOS JOS AND VASCONCELLOS MAZ. 2000. Advances in SHRIMP geochronology and their impact on understanding the tectonic and metallogenic evolution of southern Brazil: Australian Jour Earth Sci 47: 829-843.

HARTMANN LA AND NARDI LVS. 1982. Os granitos Santo Afonso, Saibro e Vauthier da região do Arroio Santa Maria Chico, Dom Pedrito, RS - Geologia, petrografia e química de elementos maiores, com interpretação geotectônica. Acta Geol Leopold VI(12): 23-36.

HARTMANN LA, PHILIPP RP, LIU D, WAN Y, WANG Y, SANTOS JOS AND VASCONCELlOS MAZ. 2004. Paleoproterozoic magmatic provenance of detrital zircons, Porongos Complex quartzites, southern Brazilian Shield: Intern Geol Rev 46: 127-157.

HARTMANN LA, PHILIPP RP, SANTOS JOS AND MCNAUGHTON NJ. 2011. Time frame of 753-680 Ma juvenile accretion during the São Gabriel orogeny, southern Brazilian Shield. Gond Res 19: 84-99.

HARTMANN LA AND SANTOS JOS. 2004. Predominance of high $\mathrm{Th} / \mathrm{U}$, magmatic zircon in Brazilian shield sandstones. Geology 32: 73-76.
HARTMANN LA, SANTOS JOS, LEITE JAD, PORChER CC AND MCNAUGHTON NJ. 2003. Metamorphic evolution and $\mathrm{U}-\mathrm{Pb}$ zircon SHRIMP geochronology of the Belizário ultramafic amphibolite, Encantadas Complex, southernmost Brazil. An Acad Brasil Cienc 75: 393-403.

HARTMANN LA, SANTOS JOS AND MCNAUGHTON NJ. 2008. Detrital zircon U-Pb age data, and Precambrian provenance of the Paleozoic Guaritas Formation, southern Brazilian Shield. Intern Geol Rev 50: 364-374.

HASUI Y, CARNEIRO CDR AND COIMBRA AW. 1975. The Ribeira folded belt. Rev Bras Geoc 5: 257-266.

Heilbron M, Pedrosa-SoARes A, Neto M, Silva LC, TROUW R AND JANASI V. 2004. Brasiliano orogens in southeast and south Brazil. In: Weinberg R, Trouw R, Fuck RA and Hackspacher P (Eds), The 750-550 Ma Brasiliano Event of South America, Journal of the Virtual Explorer, 17. Paper 4. Available at: http:/www.virtualexplorer.com. au/journal/2004/17/.

JOST H AND BITENCOURT MF. 1980. Estratigrafia e tectônica de uma fração da Faixa de Dobramentos de Tijucas no Rio Grande do Sul. Acta Geol Leopold 4: 27-60.

Jost H AND HARTMANN LA. 1984. Província MantiqueiraSetor Meridional. In: Almeida FFM and Hasui Y (Eds), O Pré-Cambriano do Brasil. Edgard Blucher, São Paulo, p. 345-368.

KOESTER E, SOLIANi JR E, LEITE JAD, HARTMANN LA, FERNANDES LAD, MCNAUGHTON NJ, SANTOS JOS AND OLIVEIRA LD. 1999. SHRIMP U-Pb age for the emplacement of the Santana Granite and reactivation of the Porto Alegre Suture, southern Brazil. Jour S Am Earth Sci 14: 91-99.

LEITE JAD, HARTMANN LA, FERNANDES LAD, MCNAUGHTON NJ, SOliAni JR E, KOESTER E, SANTOS JOS AND VASCONCELLOS MAZ. 2000. Zircon U/Pb SHRIMP dating of gneissic basement of the Dom Feliciano Belt, southernmost Brazil. J South Am Earth Sci 13: 739750.

LEITE JAD, HARTMANN LA, MCNAUGHTON NJ AND CHEMALE JR F. 1998. SHRIMP U/Pb Zircon geochronology of Neoproterozoic juvenile and crustalreworked terranes in southernmost Brazil. Int Geol Rev 40: 688-705.

LENA LOF, PIMENTEL MM, PHILIPP RP, ARMSTRONG R AND SATO K. 2014. The evolution of the Neoproterozoic São Gabriel juvenile terrane, southern Brazil based on high spatial resolution $\mathrm{U}-\mathrm{Pb}$ ages and $\partial^{18} \mathrm{O}$ data from detrital zircons. Prec Res 247: 126-138.

LOPES AP AND HARTMANN LA. 2003. Geoquímica de rochas metabasálticas da Mina da Palma, Bloco São Gabriel, Escudo Sul-Riograndense: Um possível platô oceânico. Pesquisas em Geociências 30: 27-39.

Lopes CG, Pimentel MM, Philipp RP, GRuber L, ARMSTRONG R AND JUNGES S. 2014. Provenance of the Passo Feio Complex, Dom Feliciano Belt: implications for the age of supracrustal rocks of the São Gabriel Arc, southern Brazil. J South Am Earth Sci 58: 9-17. 
MACHAdO N, Koppe JC AND HARTMANN LA. 1990. A late Proterozoic U-Pb age for the Bossoroca Belt, Rio Grande do Sul, Brazil. J South Am Earth Sci 3: 87-90.

MILANI EJ, FACCINI UF, SCHERER CM, ARAÚJO LM AND CUPERTINO JA. 1998. Sequences and stratigraphic hierarchy of the Paraná basin (Ordovician to Cretaceous), southern Brazil. Bol IG-USP Sér Científica 29: 125-173.

MILligAN PR AND GUNN PJ. 1997. Enhancement and presentation of airborne geophysical data. AGSO J Austr Geol Geophys 17: 63-75

NABIGHIAN MN. 1972. The analytic signal of two-dimensional magnetic bodies with polygonal cross-section: Its properties and use for automated anomaly interpretation. Geophysics 37: 507-517.

NABIGHIAN MN. 1974. Additional comments on the analytic signal of two-dimensional magnetic bodies with polygonal cross-section. Geophysics 39: 85-92.

NABIGHIAN MN, GRAUCH VJS, HANSEN RO, LAFEHR TR, LI Y, PEIRCE JW, PHILLIPS JD AND RUDER ME. 2005. The historical development of the magnetic method in exploration. Geophysics 70: 33ND-61ND.

NARDI LVS AND BITENCOURT MF. 1989. Geologia, petrologia e geoquímica do Complexo Granítico de Caçapava do Sul, RS. Rev Bras Geoc 19: 153-169.

NARDI LVS AND BONIN B. 1991. Post-orogenic and nonorogenic alkaline granite associations: the Saibro intrusive suite, southern Brazil - A case study. Chemical Geology 92: 197-211.

NARDi LVS, CID JP AND BITENCOURT MF. 2007. Minette mafic microgranular enclaves and their relationship to host syenites in systems formed at mantle pressures: major and trace element evidence from the Piquiri Syenite Massif, southernmost Brazil. Mineral Petrol 91: 101-116.

NARDI LVS AND FRANTZ JC. 1995. The Cordilheira Intrusive Suite: Late Proterozoic peraluminous granitoids from southern Brazil. J S Am Earth Sci 8: 55-63.

PEdrosa JR NC, VidotTi RM, FUCK RA, Oliveira KML AND CASTElo BRANCO RMG. 2015. Structural framework of the Jaibaras rift, Brazil, based on geophysical data. Jour S Am Earth Sci 58: 318-334.

PHILIPP RP, LUSA M AND NARDI LVS. 2008. Geochemistry and petrology of dioritic, tonalitic and trondhjemitic gneisses from Encantadas Complex, Santana da Boa Vista, southernmost Brazil: a Paleoproterozoic continental-arc magmatism. An Acad Bras Cienc 80: 735-748.

PHILIPP RP AND MACHADO R. 2005. The late Neoproterozoic granitoid magmatism of the Pelotas Batholith, southern Brazil. J South Am Earth Sci 19: 461-478.

Philipp RP, MASSONNE HJ AND CAMPos RS. 2013. Peraluminous leucogranites of the Cordilheira Suite: A record of Neoproterozoic and the generation of the Pelotas Batholith, Dom Feliciano Belt, Southern Brazil. J South Am Earth Sci 43: 8-24.

Pilkington M. 2007. Aeromagnetic surveying. In: Gubbins E et al. (Eds), Encyclopedia of Geomagnetism and Paleomagnetism, Dordrecht: Springer, Dordrecht, Netherlands, p. A1-A3.

RAJARAM M AND ANAND SP. 2014. Aeromagnetic signatures of Precambrian shield and suture zones of Peninsular India. Geoscience Frontiers 5: 3-15.

REMUS MVD, HARTMANN LA, MCNAUGHTON NJ, GROVES DI AND FLETCHER IR. 2000a. The link between hydrothermal epigenetic copper mineralization and the Caçapava Granite of the Brasiliano Cycle in southern Brazil. J South Am Earth Sci 13: 191-216.

REMUS MVD, HARTMANN LA, MCNAUGHTON NJ, GROVES DI AND REISCHL JL. 2000b. Distal magmatichydrothermal origin for the Camaquã $\mathrm{Cu}(\mathrm{Au}-\mathrm{Ag})$ and Santa Maria $\mathrm{Pb}, \mathrm{Zn}(\mathrm{Cu}-\mathrm{Ag})$ deposits, southern Brazil. Gondw Res 3: 155-174.

REMUS MVD, MCNAUGHTON NJ, HARTMANN LA, KopPE JC, FLeTCHER IR, GROVES DI AND PINTO VM. 1999. Gold in the Neoproterozoic juvenile Bossoroca Volcanic Arc of southernmost Brazil: isotopic constraints on timing and sources. J South Am Earth Sci 12: 349-366.

ROEST WR, VERHOEF J AND PILKINGTON M. 1992. Magnetic interpretation using the 3-D analytic signal. Geophysics 57: 116-125.

SAALMANN K, GERDES A, LAHAYE Y, HARTMANN LA, REMUS MVD AND LÄUFER A. 2011. Multiple accretion at the eastern margin of the Rio de la Plata craton: the prolonged Brasiliano orogeny in southernmost Brazil. Intern Jour Earth Sci 100: 355-378.

SAALMANN K, HARTMANN LA AND REMUS MVD. 2005a. Tectonic evolution of two contrasting schist belts in southernmost Brazil: a plate tectonic model for the Brasiliano orogeny. Int Geol Rev 47: 1234-1259.

SAALMANN K, HARTMANN LA, REMUS MVD, KOESTER E AND CONCEIÇÃO RV. 2005b. Sm-Nd isotope geochemistry of metamorphic volcano-sedimentary successions in the São Gabriel Block, southernmost Brazil: evidence for the existence of juvenile Neoproterozoic oceanic crust to the east of the Rio de la Plata craton. Precamb Res 136: 159175.

SAALMANN K, REMUS MVD AND HARTMANN LA. 2005c. Geochemistry and crustal evolution of volcano-sedimentary successions and orthogneisses in the São Gabriel Block, southernmost Brazil-relics of Neoproterozoic magmatic arcs. Gondw Res 8: 143-161.

SAALMANN K, REMUS MVD AND HARTMANN LA. 2006 a. Tectonic evolution of the Neoproterozoic São Gabriel Block, southern Brazil-constraints on Brasiliano orogenic evolution of the Rio de la Plata cratonic margin. J South Am Earth Sci 21: 204-227.

SAALMANN K, REMUS MVD AND HARTMANN LA. $2006 \mathrm{~b}$. Structural evolution and tectonic setting of the Porongos belt, southern Brazil. Geol Mag 143: 59-88.

SALGADO L AND CARVALHO IS. 2008. Uberabatitan ribeiroi, a new titanosaur from the Marília formation (Bauru group, 
Upper Cretaceous), Minas Gerais, Brazil. Palaeontology 51: 881-901.

SANTOS JOS, HARTMANN LA, BOSSI J, CAMPAL N, SCHIPILOV A, PIÑEYRO D AND MCNAUGhton NJ. 2003. Duration of the Trans-Amazonian Cycle and correlation within South America based on U-Pb SHRIMP geochronology of the La Plata Craton, Uruguay. Intern Geol Rev 45: 27-48.

SARTORI PL AND RUEGG NG. 1979. O Complexo Granítico de São Sepé, Rio Grande do Sul, e a evolução das rochas graníticas da região orogênica do sudeste. Boletim IG, Instituto de Geociências, Universidade de São Paulo 10: 69-78.

SiLVA LC, MCNAUGHTON NJ, ARMSTRONG R, HARTMANN LA AND FLETCHER IR. 2005. The neoproterozoic
Mantiqueira Province and its African connections: a zircon-based $\mathrm{U}-\mathrm{Pb}$ geochronologic subdivision for the Brasiliano/Pan-African systems of orogens. Precamb Res 136: 203-240.

SOLIANI JR E. 1986. Os dados geocronológicos do Escudo SulRio-Grandense e suas implicações de ordem geotectônica. $\mathrm{PhD}$ thesis, Universidade de São Paulo, São Paulo, 425 p.

SOMMER CA, LIMA EF, NARDI LV, FIGUEIREDO AMG AND PIEROSAN R. 2005. Potassic and low- and high-Ti mildly alkaline volcanism in the Neoproterozoic Ramada Plateau, southernmost Brazil. Jour S Amer Earth Sci 18: 237-254.

TORSVIK TH, ROUSSE S, LABAILS C AND SMETHURST MA. 2009. A new scheme for the opening of the South Atlantic Ocean and the dissection of an Aptian salt basin. Geoph J Intern 177: 1315-1333. 